\title{
MATERNAL AND FOETAL OUTCOME IN PREGNANCIES WITH BORDERLINE AMNIOTIC FLUID INDEX IN A STUDY IN A TERTIARY CARE HOSPITAL
}

\author{
Sivagami Sundari Sathiya Kumaran', Vengadeswari Ramakrishnan ${ }^{2}$ \\ ${ }^{1}$ Assistant Professor, Department of Obstetrics and Gynaecology, Government Villupuram Medical College, Villupuram. \\ ${ }^{2}$ Associate Professor, Department of Obstetrics and Gynaecology, Government Villupuram Medical College, Villupuram.
}

\section{ABSTRACT}

\section{BACKGROUND}

Amniotic fluid volume significantly affects the perinatal outcome, hence necessitates its measurement. Many methods are practised worldwide with every method having both advantage and limitations. Sonographic measurements help in assessing amniotic fluid volume antenatally and in intrapartum period as it is non-invasive and easy to use. Also, it is comparable with invasive methods.

\section{MATERIALS AND METHODS}

Study was conducted in Mahatma Gandhi Memorial Government Hospital, attached to KAP Viswanatham Government Medical College, Trichy. The study period was from August 2012 to April 2014. Samples were 50 in group A and 50 in group B.

Group A- Antenatal women admitted with borderline AFI 5 to $8 \mathrm{~cm}$ with singleton pregnancy who have completed 37 weeks with intact membrane.

Group B- Antenatal women with Normal AFI 8 to $24 \mathrm{~cm}$ admitted as inpatients.

\section{RESULTS}

In this study, 17 patients were below 20 years; 78 patients were between 21 to 30 years; and 5 patients were above 30 years. In this study out of 50 patients, 6,16,13 and 15 belonged to Gestational age of 37, 38, 39 and 40 weeks respectively and 6, 12, 17 and 15 patients belong to $37,38,39$ and 40 weeks of gestation respectively. The mode of delivery in this study showed that 52 patients delivered by caesarean section (LSCS) and 48 patients by Labour natural which had P value of 0.423 ( $p>0.05$ ) which is insignificant. The nature of amniotic fluid among group A was clear in 36 patients and meconium stained in 14 patients. Among group B, 78 patients had clear amniotic fluid and 22 had meconium-stained amniotic fluid. This is insignificant as the $P$ value is 0.148 ( $p>0.05$ ) which signifies that the nature of amniotic fluid does not depend solely on AFI level but also on other factors too. Implies that the mode of delivery doesn't significantly differ with amniotic fluid index.

\section{CONCLUSION}

Assessing amniotic fluid antenatally and intrapartum foetal surveillance in means of Amniotic fluid index and Non-stress test helps in monitoring of foetus throughout antenatal period and also during labour. Identifying the way the foetus behaves during labour in borderline amniotic fluid index patients by means of foetal heart rate tracings (NST) helps in picking up foetal distress earlier and leads to deliver a neonate with good Apgar reducing the perinatal adverse outcome.

\section{KEYWORDS}

Amniotic Fluid Index, Borderline, Maternal Outcome, Foetal Outcome.

HOW TO CITE THIS ARTICLE: Kumaran SSS, Ramakrishnan V. Maternal and foetal outcome in pregnancies with borderline amniotic fluid index in a study in a tertiary care hospital. J. Evolution Med. Dent. Sci. 2017;6(23):1910-1916, D0I: $10.14260 /$ Jemds/2017/419

\section{BACKGROUND}

Amniotic fluid is the fluid in the amniotic cavity which gives the protective environment for foetus to nourish, breathe, utilise nutrients and grow. It has got a dynamic physiology throughout pregnancy enriching the foetal growth. Amniotic fluid volume significantly affects the perinatal outcome, hence necessitates its measurement.1,2 Many methods are practised worldwide with every method having both advantage and limitations. Sonographic measurements help in assessing amniotic fluid volume $3,4,5$ antenatally and intrapartum period as it is non-invasive and easy to use.

Financial or Other, Competing Interest: None.

Submission 27-02-2017, Peer Review 12-03-2017,

Acceptance 14-03-2017, Published 20-03-2017.

Corresponding Author:

Dr. Sivagami Sundari Sathiya Kumaran,

\#274, Sudhagar Nagar

Villupuram-605602.

E-mail: sisu.mmc@gmail.com

DOI: $10.14260 / j e m d s / 2017 / 419$

(c) (i) () $\Theta$
Also, it is comparable with invasive methods. Amniotic fluid index is the sonographic method used to assess the amniotic fluid volume expressed in various figures by different groups. On the whole, it is used to assess the foetal wellbeing as it comes as a part of biophysical profile as an integral part. 6, 7 Score 8 and above though is considered normal, weightage given more to amniotic fluid score and decided with it.

Perinatal outcome as per the various studies conducted and analysed retrospectively shows that it has been adversely affected in pregnancies with oligohydramnios. Hence, it signifies the monitoring of patients with reduced amniotic fluid and during intrapartum period.

The study carried out was to observe the maternal and foetal outcome in Borderline Amniotic fluid index patients and to assess the need for monitoring in these patients.

\section{The aims of this Study are as follows-}

1. To observe and assess the foetal outcome in pregnancies with Borderline Amniotic fluid index with using sonographic method using Amniotic fluid index as principle and Non-stress test (cardiotocogram during labour) as tools. 
2. Assessing the maternal outcome in pregnancies with Borderline Amniotic fluid index with effect of borderline amniotic fluid as such on maternal conditions such as mode of delivery and after delivery effects.

3. Assessing the need for monitoring the pregnancies with Borderline Amniotic Fluid Index.

\section{MATERIALS AND METHODS}

\section{Place of Study}

Study conducted in Mahatma Gandhi Memorial Government Hospital, attached to KAP Viswanatham Government Medical College, Trichy.

\section{Study Period}

August 2012 to April 2014.

\section{Sample Size}

50 in group A and 50 in group B.

\section{Group A}

Antenatal women admitted with borderline AFI 5 to $8 \mathrm{~cm}$ with singleton pregnancy who have completed 37 weeks with intact membrane.

\section{Group B}

Antenatal women with Normal AFI 8 to $24 \mathrm{~cm}$ admitted as inpatients.

\section{Sampling Procedure}

Patients admitted as inpatients in Obstetrics and Gynaecology Department in Mahatma Gandhi Memorial Government Hospital were selected as per inclusion and exclusion criteria and categorised into group A and group B respectively.

\section{Inclusion Criteria}

1. Single live intrauterine gestation with cephalic presentation.

2. AFI from 5 to $8 \mathrm{~cm}$.

3. 37 completed weeks of gestation.

4. Intact membrane.

\section{Exclusion Criteria}

1. AFI less than 5 and more than 8 .

2. Gestational age less than 37 completed weeks.

3. Post-term.

4. Associated foetal malformations.

5. Ruptured membranes.

6. Malpresentation and multiple gestations.

\section{High Risk Pregnancy:}

1. Placental insufficiency
a. Hypertension.
b. Preeclampsia.
c. Diabetes.
d. Hypovolaemia.
e. Chronic renal disease.
f. Connective tissue disorders.

2. Abruption.

3. Prostaglandin synthetase inhibitors therapy.

4. Angiotensinogen converting enzyme inhibitors therapy.
The pregnancies with foetal malformations were also excluded from the study.

\section{Procedure}

All patients both in group A and group B are informed about the condition and informed written consent was obtained after explaining the procedure, their AFI, and absence of adverse effects in the study ensuring that their foetus will be monitoring all the time and no adverse effect will be on foetus. Detailed history was elicited and recorded. General examination, Systemic examination and Obstetric examination was carried. Investigated for urine routine, $\mathrm{Hb}$, Blood grouping and typing, Random blood sugar, BT, CT were done. Ultrasonogram was done and documented.

On admission, NST was done for all women in both groups.

If NST found reactive, then further management was done according to protocol and if non-reactive, Emergency LSCS was done (not if patients is in active labour who will deliver immediately).

If patient is in labour (i.e. less than $3 \mathrm{~cm}$ in primigravida and less than $4 \mathrm{~cm}$ in multigravida are included in study), oxytocin drip started. Women if not in labour Bishop's scoring done. Oxytocin is started if cervix is favourable. Induced with Dinoprostone gel in patients of unfavourable cervix. The Bishop's score after 6 to 8 hours of instillation reassessed. If in labour, oxytocin drip is started. If not in labour watched for another 6 to 8 hours. Patients are taken for emergency LSCS if no progress.

All patients were monitored by NST in labour. For any signs of foetal distress, emergency LSCS done.

After 3-centimetre dilatation of the cervical os in primigravida and $4 \mathrm{~cm}$ dilatation in multigravida, ARM was done and classified as clear and meconium stained liquor. Patients with meconium-stained liquor were taken for emergency LSCS.

All newborns were attended by Paediatrician.

Various outcome measures recorded are induced vs. spontaneous labour, nature of amniotic fluid, FHR tracings, mode of delivery, indication for caesarean section or instrumental delivery, APGAR score at 1 minutes and 5 minutes, birth weight, admission to neonatal ward, perinatal morbidity and mortality.

\section{RESULTS}

In this study, 17 patients were below 20 years; 78 patients were between 21 to 30 years; and 5 patients were above 30 years. Applying chi-square test there is no statistical difference between the group A and group B. P value is 0.312 ( $p>0.05)$ which is insignificant as in table 1 .

\begin{tabular}{|c|c|c|c|c|}
\hline Age & $\begin{array}{c}\text { Group A } \\
(\mathbf{n = 5 0 )}\end{array}$ & $\begin{array}{c}\text { Group B } \\
(\mathbf{n = 5 0 )}\end{array}$ & $\begin{array}{c}\text { Total } \\
(\mathbf{n = 1 0 0 )})\end{array}$ & $\begin{array}{c}\text { Statistical } \\
\text { Difference }\end{array}$ \\
\hline $\begin{array}{c}\text { Below } \\
20 \text { yrs. }\end{array}$ & $\begin{array}{c}7 \\
(14 \%)\end{array}$ & $\begin{array}{c}10 \\
(20 \%)\end{array}$ & $\begin{array}{c}17 \\
(17 \%)\end{array}$ & $\begin{array}{c}\mathrm{X}^{2}=2.329 \\
\mathrm{df}=2\end{array}$ \\
\hline $\begin{array}{c}21 \text { to } 30 \\
\text { yrs. }\end{array}$ & $\begin{array}{c}39 \\
(78 \%)\end{array}$ & $\begin{array}{c}39 \\
(78 \%)\end{array}$ & $\begin{array}{c}78 \\
(78 \%)\end{array}$ & $.312>0.05$ \\
\hline $\begin{array}{c}\text { Above } 30 \\
\text { yrs. }\end{array}$ & $\begin{array}{c}4 \\
(8 \%)\end{array}$ & $\begin{array}{c}1 \\
(2 \%)\end{array}$ & $\begin{array}{c}5 \\
(5 \%)\end{array}$ & Not Significant \\
\hline \multicolumn{5}{|c}{ Table 1 } \\
\hline
\end{tabular}

Comparing the parity both groups are comparable as there is no statistical difference. 58 patients were 
Primigravida, 30 patients were gravida 2, 11 patients were gravida 3, 1 patient was gravida 4. Applying Chi-square test which showed a P value $0.638(\mathrm{p}>0.05)$ which is insignificant as in table 2 .

\begin{tabular}{|c|c|c|c|c|}
\hline $\begin{array}{c}\text { Obstetric } \\
\text { Code }\end{array}$ & $\begin{array}{c}\text { Group A } \\
(\mathbf{n = 5 0 )}\end{array}$ & $\begin{array}{c}\text { Group B } \\
(\mathbf{n = 5 0 )}\end{array}$ & $\begin{array}{c}\text { Total } \\
(\mathbf{n = 1 0 0})\end{array}$ & $\begin{array}{c}\text { Statistical } \\
\text { Difference }\end{array}$ \\
\hline Primi & $28(56 \%)$ & $30(60 \%)$ & $58(58 \%)$ & $\begin{array}{c}\mathrm{X}^{2}=1.693 \\
\mathrm{df}=3\end{array}$ \\
\hline G2 & $17(34 \%)$ & $13(26 \%)$ & $30(30 \%)$ & $.638(\mathrm{p}>0.05)$ \\
\hline G3 & $5(10 \%)$ & $6(12 \%)$ & $11(11 \%)$ & Not Significant \\
\hline G4 & 0 & $1(2 \%)$ & $1(1 \%)$ & \\
\hline \multicolumn{5}{|c|}{ Table 2 } \\
\hline
\end{tabular}

In this study out of 50 patients, 6, 16, 13 and 15 belonged to Gestational age of $37,38,39$ and 40 weeks respectively and $6,12,17$ and 15 patients belonged to $37,38,39$ and 40 weeks of gestation respectively. The $P$ value is 0.776 ( $p>0.05$ ), which is insignificant as shown in table 3.

\begin{tabular}{|c|c|c|c|c|}
\hline $\begin{array}{c}\text { Gestational } \\
\text { Age } \\
\text { (Weeks) }\end{array}$ & $\begin{array}{c}\text { Group A } \\
(\mathbf{n = 5 0 )}\end{array}$ & $\begin{array}{c}\text { Group B } \\
(\mathbf{n = 5 0 )}\end{array}$ & $\begin{array}{c}\text { Total } \\
(\mathbf{n = 1 0 0 )}\end{array}$ & $\begin{array}{c}\text { Statistical } \\
\text { Difference }\end{array}$ \\
\hline 37 & $6(12 \%)$ & $6(12 \%)$ & $\begin{array}{c}12 \\
(12 \%)\end{array}$ & $\begin{array}{c}\mathrm{X}^{2}=1.105 \\
\mathrm{df}=3\end{array}$ \\
\hline 38 & $16(32 \%)$ & $12(24 \%)$ & $\begin{array}{c}28 \\
(28 \%)\end{array}$ & $.776(\mathrm{p}>0.05$ \\
\hline 39 & $13(26 \%)$ & $17(34 \%)$ & $\begin{array}{c}30 \\
(30 \%)\end{array}$ & $\begin{array}{c}\text { Not } \\
\text { Significant }\end{array}$ \\
\hline 40 & $15(30 \%)$ & $15(30 \%)$ & $30(30 \%)$ & \\
\hline \multicolumn{5}{|c}{ Table 3 } \\
\hline \multicolumn{5}{|c}{} \\
\cline { 1 - 3 } & \multicolumn{4}{c}{} \\
\hline
\end{tabular}

The distribution of group A in respect to Amniotic fluid index showed out of 50 patients, 10 were with AFI $5 \mathrm{~cm}, 11$ with AFI $6 \mathrm{~cm}, 13$ with AFI $7 \mathrm{~cm}$ and 16 with AFI $8 \mathrm{~cm}$ distributed as $20 \%, 22 \%, 26 \%$ and $32 \%$ of patients with AFI $5,6,7$ and $8 \mathrm{~cm}$ respectively.

Among the Group B, the distribution of patients was 12 with AFI $9 \mathrm{~cm}, 11$ with AFI $10 \mathrm{~cm}, 10$ with AFI $11 \mathrm{~cm}, 8$ with AFI $12 \mathrm{~cm}, 4$ with AFI $13 \mathrm{~cm}, 5$ with AFI $14 \mathrm{~cm}$ with 24\%, $22 \%, 20 \%, 16 \%, 8 \%$, and $10 \%$ distribution of AFI 9, 10, 11 , 12,13 and $14 \mathrm{~cm}$.

In this study, the tool used to monitor the patients was Non-Stress test which showed Non-Reactive test in 27 patients in group A and 15 patients in group B. Reactive test in 23 patients in group A, 35 in group B. Applying Chi-square test, the $P$ value was $0.015(p<0.05)$ which is significant which implies that foetal distress is more among group $A$ and signifies that with decreasing AFI perinatal risk increases (Table 4).

\begin{tabular}{|c|c|c|c|c|}
\hline NST & $\begin{array}{c}\text { Group A } \\
(\mathbf{n = 5 0 )}\end{array}$ & $\begin{array}{c}\text { Group B } \\
(\mathbf{n = 5 0 )}\end{array}$ & $\begin{array}{c}\text { Total } \\
(\mathbf{n = 1 0 0 )}\end{array}$ & $\begin{array}{c}\text { Statistical } \\
\text { Difference }\end{array}$ \\
\hline $\begin{array}{c}\text { Non- } \\
\text { Reactive }\end{array}$ & $27(54 \%)$ & $15(30 \%)$ & $42(42 \%)$ & $\begin{array}{c}\mathrm{X}^{2}=5.911 \\
\mathrm{df}=1 \\
.015(\mathrm{p}<0.05) \\
\text { Significant }\end{array}$ \\
\cline { 1 - 4 } Reactive & $23(46 \%)$ & $35(70 \%)$ & $58(58 \%)$ & $\begin{array}{c}0 \\
\text { Table 4. Shows Non-Stress Test }\end{array}$ \\
\hline \multicolumn{5}{|c|}{} \\
\hline
\end{tabular}

The foetal heart pattern had significant difference between two groups as variable deceleration and late deceleration are more in group A i.e. $57.7 \%$ had variable deceleration and $19.2 \%$ had late decelerations respectively. Chi-square test showed the P value of $0.021(p<0.05)$ which is significant indicates that with amniotic fluid reducing foetal distress increases as shown in Table 5.

\begin{tabular}{|c|c|c|c|c|}
\hline $\begin{array}{c}\text { FH } \\
\text { Pattern }\end{array}$ & $\begin{array}{c}\text { Group A } \\
(n=50)\end{array}$ & $\begin{array}{c}\text { Group B } \\
(n=50)\end{array}$ & $\begin{array}{c}\text { Total } \\
(n=100)\end{array}$ & \begin{tabular}{|l|} 
Statistical \\
Difference
\end{tabular} \\
\hline $\begin{array}{c}\text { Early } \\
\text { Decele- } \\
\text { ration }\end{array}$ & $6(23.1 \%)$ & $6(40 \%)$ & $12(29.3 \%)$ & \multirow{3}{*}{$\begin{array}{c}\mathrm{X}^{2}=1.989 \\
\mathrm{df}=2 \\
0.021 \\
(\mathrm{p}<0.05) \\
\text { Significant }\end{array}$} \\
\hline $\begin{array}{l}\text { Variable } \\
\text { Dece- } \\
\text { leration }\end{array}$ & 15 (57.7\%) & $8(53.3 \%)$ & $23(56.1 \%)$ & \\
\hline $\begin{array}{c}\text { Late } \\
\text { Decelera- } \\
\text { tion }\end{array}$ & $5(19.2 \%)$ & $1(6.7 \%)$ & $6(14.6 \%)$ & \\
\hline & Table. 5 & vs Foet & Ieart Patter & \\
\hline
\end{tabular}

\begin{tabular}{|c|c|c|c|c|}
\hline $\begin{array}{c}\text { Induced/ } \\
\text { Sponta- } \\
\text { neous }\end{array}$ & $\begin{array}{c}\text { Group A } \\
(n=50)\end{array}$ & $\begin{array}{c}\text { Group B } \\
(n=50)\end{array}$ & $\begin{array}{c}\text { Total } \\
(n=100)\end{array}$ & $\begin{array}{l}\text { Statistical } \\
\text { Difference }\end{array}$ \\
\hline I & $\begin{array}{c}23 \\
(46 \%) \\
\end{array}$ & $23(46 \%)$ & $46(46 \%)$ & $\begin{array}{c}\mathrm{X}^{2}=.000 \\
\mathrm{df}=1\end{array}$ \\
\hline $\mathrm{S}$ & $\begin{array}{c}27 \\
(54 \%)\end{array}$ & $27(54 \%)$ & $54(54 \%)$ & $\begin{array}{c}(p>0.05) \\
\quad \text { Not } \\
\text { Significant }\end{array}$ \\
\hline
\end{tabular}

Table 6. Onset of Labour

In this study, comparing the onset of labour whether it is spontaneous or induced it was comparable as 46 patients were induced and 56 patients went into spontaneous labour with $P$ value of $1.00 \quad(p>0.05)$ which is not significant. (Table 6).

The mode of delivery in this study showed that 52 patients delivered by caesarean section (LSCS) and 48 patients by Labour natural which had $P$ value of 0.423 ( $>0.05)$ which is insignificant. This implies the mode of delivery doesn't significantly differ with amniotic fluid index as in Table 7.

\begin{tabular}{|c|c|c|c|c|}
\hline MOD & $\begin{array}{c}\text { Group A } \\
(n=50)\end{array}$ & $\begin{array}{c}\text { Group B } \\
(n=50)\end{array}$ & $\begin{array}{c}\text { Total } \\
(n=100)\end{array}$ & $\begin{array}{l}\text { Statistical } \\
\text { Difference }\end{array}$ \\
\hline LSCS & $28(56 \%)$ & $24(48 \%)$ & $52(52 \%)$ & $\begin{array}{c}\mathrm{X}^{2}=.641 \\
\mathrm{df}=1\end{array}$ \\
\hline LN/Epi & $22(44 \%)$ & $26(52 \%)$ & $48(48 \%)$ & $\begin{array}{l}.423(\mathrm{p}>0.05) \\
\text { Not Significant }\end{array}$ \\
\hline
\end{tabular}

The study showed there is no statistical difference in induction delivery interval among group $A$ and group B as 64 patients delivered within 12 hours and 36 patients delivered after more than 12 hours with Chi-square test showing $\mathrm{P}$ value of $0.211(\mathrm{p}>0.05)$ which is insignificant. Illustrated in chart 1. 


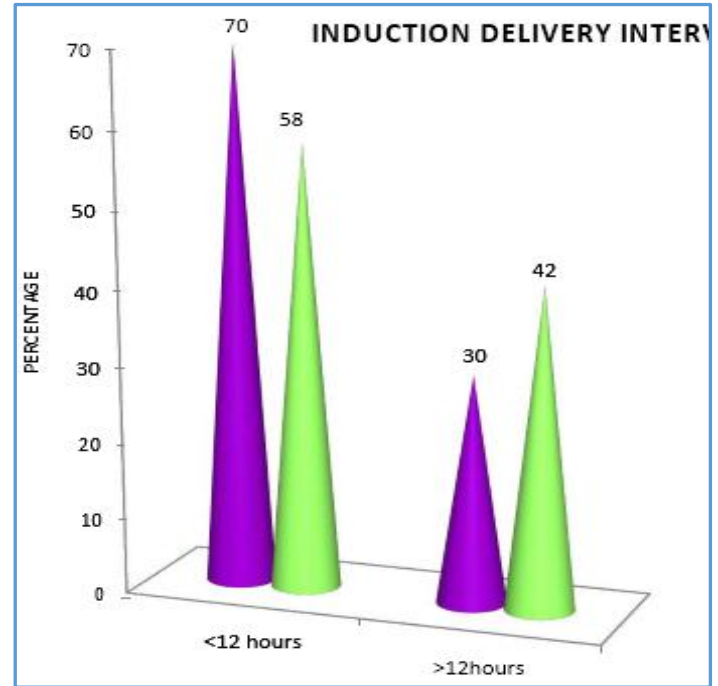

Chart 1. Induction Delivery Interval

The nature of amniotic fluid among group A was clear in 36 patients and meconium stained in 14 patients. Among group B, 42 patients had clear amniotic fluid and 8 had meconium-stained amniotic fluid. This is insignificant as the $\mathrm{P}$ value is $0.148(p>0.05)$ which signifies that the nature of amniotic fluid does not depend solely on AFI level but also on other factors too.

Birth weight data showed no significant difference with $P$ value of $0.822(p>0.05)$ as 73 patients had infants with birth weight between 2 to $3 \mathrm{~kg}$ and 27 patients had 3 to $4 \mathrm{~kg}$ babies as in Table 8.

\begin{tabular}{|c|c|c|c|c|}
\hline $\begin{array}{l}\text { B. Wt. } \\
\text { (kg) }\end{array}$ & $\begin{array}{c}\text { Group A } \\
(n=50)\end{array}$ & $\begin{array}{c}\text { Group A } \\
(n=50)\end{array}$ & $\begin{array}{c}\text { Total } \\
(n=100)\end{array}$ & $\begin{array}{l}\text { Statistical } \\
\text { Difference }\end{array}$ \\
\hline 2 to $3 \mathrm{~kg}$ & $36(72 \%)$ & 37 (74\%) & $73(73 \%)$ & $\begin{array}{c}\mathrm{X}^{2}=.051 \\
\mathrm{df}=1.822\end{array}$ \\
\hline 3 to $4 \mathrm{~kg}$ & $14(28 \%)$ & $13(26 \%)$ & $27(27 \%)$ & $\begin{array}{c}>0.05 \\
\text { Not } \\
\text { Significant }\end{array}$ \\
\hline
\end{tabular}

In this study, the effect on mother in immediate postpartum period and postnatally/post-operative period showed 71 mothers had no effects, 25 patients had fever and 4 patients had paralytic ileus which was treated. On the whole, there was no statistical difference as $\mathrm{P}$ value was 0.973 ( $p>0.05$ ) which signifies AFI solely does not affect the maternal outcome but other factors significantly lead into LSCS. Illustrated in chart 2.

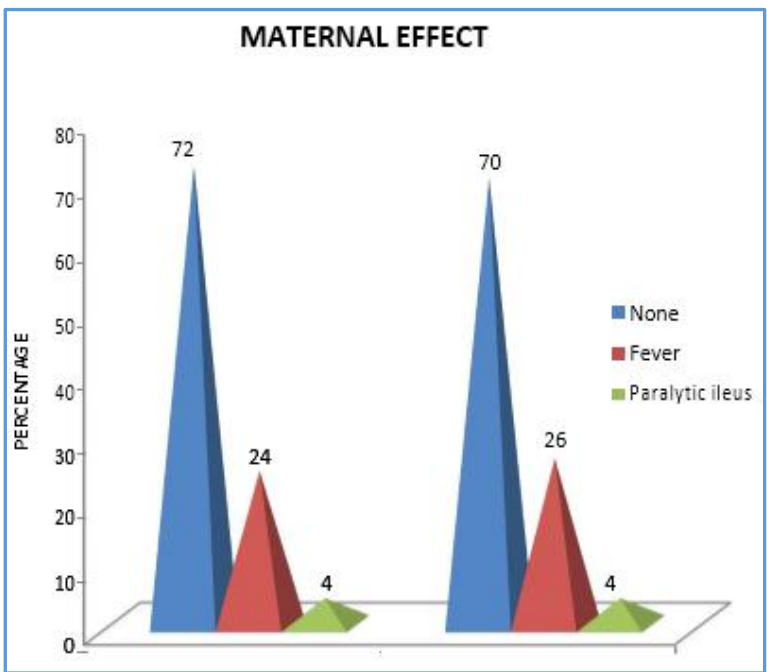

Chart 2. Maternal Effect

Newborn admissions were significantly higher among the group $\mathrm{A}$ as out of 50 infants, 32 got admitted. In group B among 50 infants, only 21 got admitted. The statistical test showed $P$ value of $0.028(p<0.05)$ which is significant. This implies that with decreasing AFI perinatal risk increases which is evident from the fact that more infants among group A needed NICU care. Illustrated in chart 3.

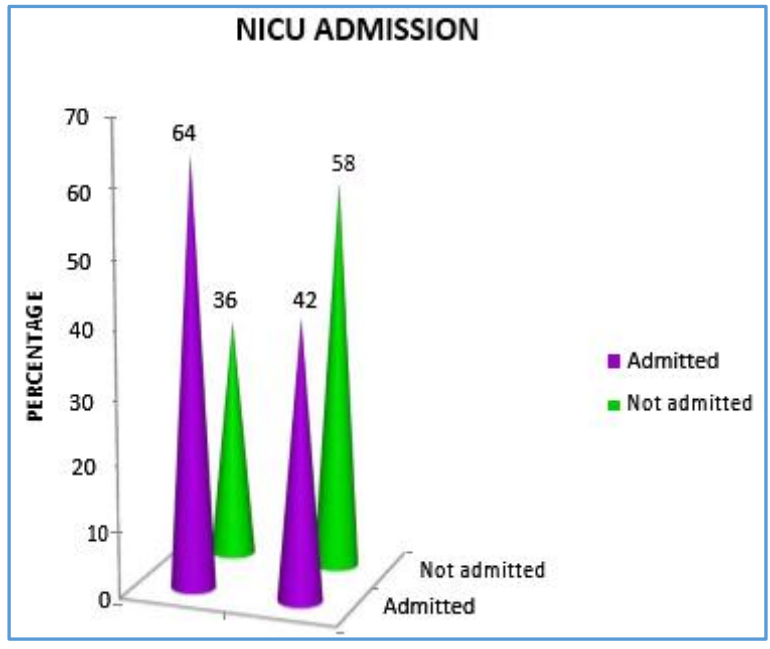

Chart 3. NICU Admission

The mode of delivery in group A was found among 50 patients, 28 had LSCS and 22 had Labour natural which showed LSCS is significantly higher in group A and also showed with decreasing AFI index, LSCS increased which is evident by 9 with AFI $5 \mathrm{~cm}, 7$ with AFI $6 \mathrm{~cm}, 6$ with AFI $7 \mathrm{~cm}$, 6 with AFI $8 \mathrm{~cm}$, and LSCS was more (32.1\%) with $5 \mathrm{~cm}$. Shown in table 9.

\begin{tabular}{|c|c|c|c|}
\hline AFI & LSCS (n=28) & LN/Epi (n=22) & Total (n=50) \\
\hline 5 & $9(32.1 \%)$ & $1(4.5 \%)$ & $10(20 \%)$ \\
\hline 6 & $7(25 \%)$ & $4(18.2 \%)$ & $11(22 \%)$ \\
\hline 7 & $6(21.4 \%)$ & $7(31.8 \%)$ & $13(26 \%)$ \\
\hline 8 & $6(21.4 \%)$ & $10(45.5 \%)$ & $16(32 \%)$ \\
\hline \multicolumn{4}{|c|}{ Table 9. Mode of Delivery in Group A } \\
\hline
\end{tabular}

Maternal effect had significant difference when compared between the induction delivery interval. Patients delivered less than 12 hours had less incidence of fever and paralytic 
ileus but patients who delivered after more than 12 hours had more incidence of fever $44.4 \%$ and $11.1 \%$ had paralytic ileus. Chi-square test showed significant difference of 0.00 $(\mathrm{p}<0.05)$ which signifies with increasing time interval maternal outcome significantly differs. Shown in table 10.

\begin{tabular}{|c|c|c|c|c|}
\hline \multirow{2}{*}{$\begin{array}{c}\text { Maternal } \\
\text { Effect }\end{array}$} & \multicolumn{3}{|c|}{ Induction Delivery Interval } & \multirow{2}{*}{$\begin{array}{c}\text { Statisti-cal } \\
\text { Inference }\end{array}$} \\
\cline { 2 - 5 } & $<12$ hrs (n=64) & $>12$ hrs (n=36) & Total (n=50) & $\mathrm{X}^{2}=21.205$ \\
$\mathrm{df}=2.000$ & $71(71 \%)$ & $(\mathrm{p}<0.05)$ \\
\hline No effect & $55(85.9 \%)$ & $16(44.4 \%)$ & $25(25 \%)$ & Significant \\
\hline Fever & $9(14.1 \%)$ & $16(44.4 \%)$ & $4(4 \%)$ & \\
\hline Paralytic ileus & 0 & $4(11.1 \%)$ & \multicolumn{3}{c}{} \\
\hline \multicolumn{4}{r}{}
\end{tabular}

Mode of delivery among reactive NST patients showed 17 by LSCS and 41 by Labour natural with no statistical difference among both groups as the $\mathrm{P}$ value was 0.304 ( $p>0.05$ ) which is insignificant.

Among the group A, who had the Non-Reactive NST i.e. 27 patients, 23 had LSCS and 4 had Labour natural. The statistical difference with $P$ value $0.023(\mathrm{p}<0.05)$ indicates that with reducing AFI Non-Reactive NST increases and leads to more interventional mode of delivery as LSCS.

Apgar at 1 minute had no difference among both the groups, but there was difference in 5 minutes Apgar as the $P$ value was $0.018(\mathrm{p}<0.05)$ which signifies that perinatal morbidity is increased in group A means borderline AFI with decreasing liquor increases the risk of foetal distress. Shown in table 11 , chart 4.

\begin{tabular}{|c|c|c|c|}
\hline $\begin{array}{c}\text { Apgar } \\
\text { 1 min. }\end{array}$ & Mean & Standard deviation & Statistical difference \\
\hline Group A ( $\mathrm{n}=50)$ & 7.28 & .948 & $\begin{array}{c}\mathrm{T}=-.101 \mathrm{Df}=98 \\
.920(\mathrm{p}>0.05) \\
\text { Not Significant }\end{array}$ \\
\hline Group B ( $\mathrm{n}=50)$ & 7.30 & 1.035 & Statistical Difference \\
\hline Apgar 5 min. & Mean & Standard deviation & $\begin{array}{c}\mathrm{T}=-2.167 \mathrm{Df}=98 \\
.018(\mathrm{p}<0.05) \\
\text { Significant }\end{array}$ \\
\hline Group A ( $\mathrm{n}=50)$ & 8.62 & .602 & .598 \\
\hline Group B ( $\mathrm{n}=50)$ & 8.64 & Table 11. Apgar at "1 minute" and "5 minutes" \\
\hline
\end{tabular}

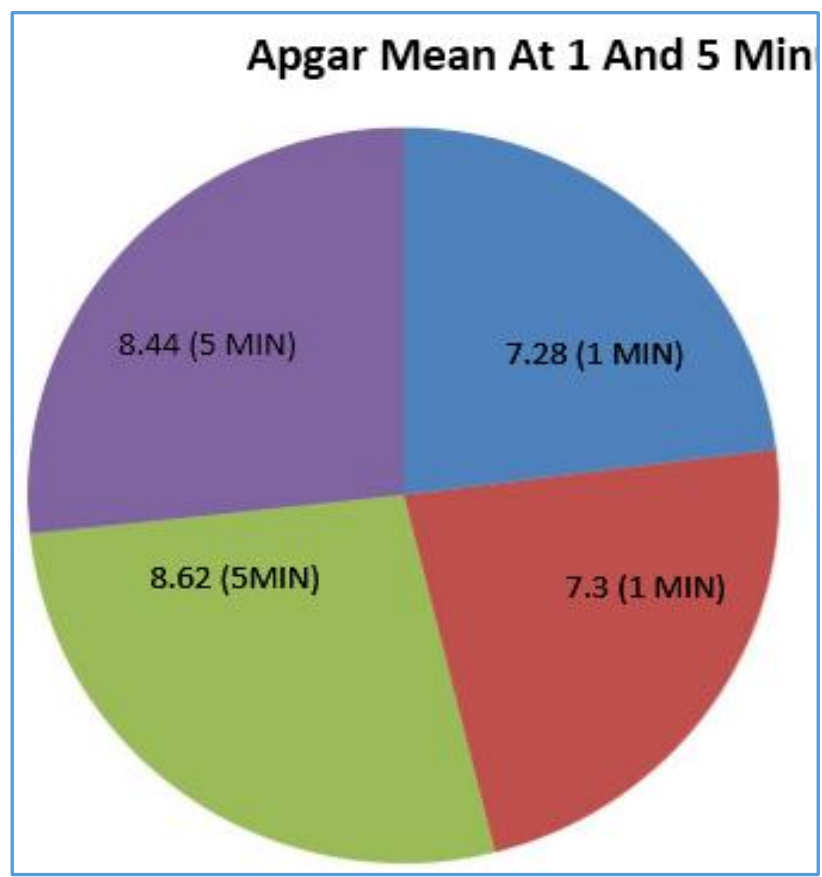

Chart 4. Apgar at "1 minute" and "5 minutes"

\section{DISCUSSION}

Amniotic fluid is the protective milieu that nourishes the foetus and in process of labour it helps the foetus to maintain the acid-base balance so that it does not go into distress. With decreasing amniotic fluid, the foetus may have increased perinatal risk. 8,9
In this study, perinatal risk is assessed in aspect of decreasing amniotic fluid level measured as AFI; Borderline AFI 5 to $8 \mathrm{~cm}$ and its impact in perinatal outcome and indirectly maternal outcome. ${ }^{10,11,12}$

Phelan et al studied about the amniotic fluid index measurements during pregnancy and concluded that its usefulness in assessing the foetal surveillance throughout pregnancy.

Amniotic fluid index is a useful screening test for detecting intrapartum foetal distress and early intervention to deliver an infant with good Apgar. Colleen and Mark et al studied the impact of amniotic fluid volume assessed intrapartum on perinatal outcome concluded that it is good in predicting the risk. $13,14,15$

In the study, the impact of borderline AFI is studied and the outcome signifies that perinatal risk can be assessed by amniotic fluid index.

In the study carried out, Non-Reactive pattern of NST was more in group A, 54\% had Non-Reactive NST. Erika et al ${ }^{16,17}$ concluded in their study as borderline AFI had 2-fold increase of adverse perinatal outcome in the borderline AFI group with regards to Non-Reactive NST and meconium-stained amniotic fluid.

In this study of foetal heart pattern in reference to decelerations, $52 \%$ had deceleration in intrapartum monitoring compared to $30 \%$ in group B. Jeng et al 18,19 observed non-reassuring foetal heart tracings for which caesarean deliveries were carried out and David et al ${ }^{20,21}$ in 
their study observed decelerations in borderline AFI group and two-fold increase in perinatal risk.

The mode of delivery had no significant difference as $56 \%$ of group A had LSCS and 48\% had LSCS in group B which is not statistically different. Baron et al 22,23 observed the risk associated with borderline AFI which concluded that there is no statistical difference in caesarean deliveries in both groups.

NICU admission was $64 \%$ in group A compared with $42 \%$ in group $B$ as concluded in Kwon et al. Gumus et al ${ }^{24}$ observed that neonatal unit admissions were higher in borderline AFI group. Banks et al observed more NICU admissions in borderline AFI group. ${ }^{25,26,27}$

Apgar at 5 minutes had showed significant deviation from group B. Apgar at 5 minutes less than 7 in one group was found to be higher in other group with mean of 8.62 and SD of 0.602 . Maryam Asgharnia et $\mathrm{al}^{28}$ in an Iranian based study observed that more incidences of Apgar less than 7 at 5 minutes and neonatal unit admission. Kreiser et al studied the effect of borderline AFI and observed that Apgar at 5 minutes to be less than 7.29, 30

In the study, $56 \%$ of group A had LSCS with $32 \%$ of AFI 5 cm but only $21.4 \%$ with AFI $8 \mathrm{~cm}$ had LSCS and among them $85 \%$ had Non-Reactive NST signifying that with reducing amniotic fluid index the Caesarean rate increases for foetal non-reassuring heart rate pattern. Luo et al observed that caesarean rate increases for non-reassuring foetal heart rate pattern in their study.

\section{Summary}

- In this study out of 100 patients, Demographic parameters, Age, Parity, Gestational Age were comparable in both groups.

- $\quad 78 \%$ of patients were between 21 to 30 years of age and $39 \%$ of study group belonged to this age.

- $58 \%$ of patients were primipara and $56 \%$ of group A were primipara with $30 \%$ gravida $2,11 \%$ gravida $3,1 \%$ gravida 4 and above.

- $30 \%$ of patients belonged to 39 weeks and 40 weeks of gestational age.

- $\quad$ Among the group A, 20\% got AFI $5 \mathrm{~cm}, 22 \%$ got AFI 6 $\mathrm{cm}, 26 \%$ got AFI $7 \mathrm{~cm}$ and $32 \%$ got AFI $8 \mathrm{~cm}$ and had the LSCS rate of $32 \%$ in AFI $5 \mathrm{~cm}$ group, $25 \%$ in AFI $6 \mathrm{~cm}$ group, $21.4 \%$ in AFI 7 and $8 \mathrm{~cm}$ signifying with reducing AFI more patients had interventional mode of delivery.

- $\quad 54 \%$ had Non-Reactive NST in group A which shows that foetal distress in borderline AFI is more than Normal AFI.

- Among the patients who had non-reassuring foetal heart rate pattern, $52 \%$ belonged to group A with more variable decelerations of $57.8 \%$, late decelerations of $19.2 \%$ and early decelerations of $23.1 \%$ signifying more perinatal risk in borderline AFI group.

- Onset of labour had no significant difference and induction compared with mode of delivery having no impact on perinatal outcome also as evident in many studies.

- Though the mode of delivery was not significantly different in both groups, caesarean deliveries were more with reducing AFI taken for the indication of foetal distress and persistent non-reassuring foetal heart rate tracings.
- Meconium-stained amniotic fluid was about $28 \%$ in group A compared with $16 \%$ in group B with data showing that if AFI decreases the meconium nature increases resulting in low Apgar less than 7 at 5 minutes and need of neonatal unit care.

- $\quad$ NICU admission was $64 \%$ in group A compared with only $42 \%$ in group B signifying the need of neonatal unit care in borderline AFI patients.

- Though there was no significant difference in means of birth weight, maternal effects between both groups; maternal outcome was significantly affected in respect to increased LSCS deliveries taken for non-reassuring foetal heart rate tracings; and patients who delivered after more than 12 hours from induction had increased incidence of fever and paralytic ileus; $44.4 \%$ and $4.1 \%$ compared with $14.1 \%$ and $0 \%$ of fever and paralytic ileus respectively in patients who delivered in less than 12 hours with respect to induction delivery interval.

\section{CONCLUSION}

Assessing amniotic fluid antenatally and intrapartum foetal surveillance in means of Amniotic fluid index and Non-stress test helps in monitoring of foetus throughout antenatal period and also during labour.

Though many methods are practised to measure amniotic fluid volume, amniotic fluid index is preferred for its reproducibility nature and can be repeated easily with standardisation and sensitivity to identify low volumes of amniotic fluid.

Identifying the way the foetus behaves during labour in borderline amniotic fluid index patients by means of foetal heart rate tracings (NST) helps in picking up foetal distress earlier and leads to deliver a neonate with good Apgar reducing the perinatal adverse outcome.

With reducing Amniotic fluid index there is an increase in the risk of perinatal outcome and adverse maternal effects. Monitoring patients with Borderline Amniotic fluid index is on the increasing trend in modern obstetric practice.

\section{REFERENCES}

[1] Mudaliar, Menon. Fertilisation of ovum and development of embryo: In: Gopalan S, Jain V, eds. Clinical obstetrics. 11 th edn. India: Universities Press 2012:30-1.

[2] Seeds AE: Amniotic fluid physiology. In: Sciarra JJ. edr. Gynecology and Obstetrics. Vol 3. New York: Harper \& Row 1989.

[3] Lind T, Kendall A, Hytten FE. The role of the fetus in the formation of amniotic fluid. J Obstet Gynaecol Br Commonw 1972;79(4):289-98.

[4] van Otterlo LC, Wladimiroff JW, Wallenburg HC. Relationship between fetal urine production and amniotic fluid volume in normal pregnancy and pregnancy complicated by diabetes. $\mathrm{Br}$ J Obstet Gynaecol 1977;84(3):205-9.

[5] Boddy K, Dawes GS. Fetal breathing. Br Med Bull 1975;31(1):3-7.

[6] Abramovich DR, Garden A, Jandial L, et al. Fetal swallowing and voiding in relation to hydramnios. Obstet Gynecol 1979;54(1):15-20. 
[7] Leontic EA, Schruefer JJ, Andreassen B, et al. Further evidence for the role of prolactin on human fetoplacental osmoregulation. Am J Obstet Gynecol 1979;133(4):435-8.

[8] Chamberlain PF, Manning FA, Morrison I, et al. Ultrasound evaluation of amniotic fluid volume. I. The relationship of marginal and decreased amniotic fluid volumes to perinatal outcome. Am J Obstel Gynecol 1984;150(3):245-9.

[9] Bottoms SF, Welch RA, Zador IE, et al. Limitation of usi ng maximum vertical pocket and other sonographic evaluations of amniotic fluid volume to predict fetal growth technical or physiologic? Am J Obstet Gynecol 1986;155(1):154-8.

[10] Hoddick WK, Callen PW, Filly RA, et al. Ultrasonographic determination of qualitative amniotic fluid volume in intrauterine growth retardation: reassessment of the $1 \mathrm{~cm}$ rule. Am J Obstet Gynecol 1984;149(7):758-62.

[11] Phelan JP, Ahn Mo, Smith CV, et al. Amniotic fluid index measurements during pregnancy. J Reprod Med 1987;32(8):601-4.

[12] Magann EF, Nolan TF, Hess LW, et al. Measurement of amniotic fluid volume: accuracy of ultrasonography techniques. AM J Obstet Gyneol 1992:167(6):1533-7.

[13] Moore TR, Cayle JE. The amniotic fluid index in normal human pregnancy. Am J Obstet Gynecol 1990;162(5): 1168-73.

[14] Rutherford SE, Phelan JP, Smith CV, et al. The fourquadrant assessment of amniotic fluid volume: an adjunct to antepartum fetal heart rate testing. Obstet Gynecol 1987;70(3 Pt 1):353-6.

[15] Jeng CJ, Jou TJ, Wang KG, et al. Amniotic fluid index measurement with four-quadrant technique during pregnancy. J Reprod Med 1990;35(7):674-7.

[16] Callen PW. Amniotic fluid. Its role in fetal health and disease. Ultrasound in obstetrics and gynecology. $4^{\text {th }}$ edn. Pennsylvania: Saunders 2010:644-5.

[17] Divon MY, Marks AD, Henderson CE. Longitudinal measurement of amniotic fluid index in postterm pregnancies and its association with fetal outcome. Am J Obstet Gynecol 1995;172(1 Pt 1):142-6.
[18] Lagrew DC, Pircon RA, Nageotte $M$, et al. How frequently should the amniotic fluid index be repeated? Am J Obstet Gynecol 1992;167(4 Pt 1):1129-33.

[19] Locatelli A, Vergani P, Toso L, et al. Perinatal outcome associated with oligohydramnios in uncomplicated term pregnancies. Arch Gynecol Obstet 2004;269(2):130-3.

[20] Donald I. Hydramnios and Oligohydramnios In: Renu Misra. edr. Practical obstetrics problems. $7^{\text {th }}$ edn. New Delhi: BI Publications 2014; p. 381.

[21] Kilpastrick SJ, Suffered KL, Pomeroy T, et al. Maternal hydration increases amniotic fluid index. Obstet Gynecol 1991;78(6):1098-102.

[22] Intrapartum assessment. Chapter 14. Williams Obstetrics. 21st edn. McGraw Hill 2001:330-60.

[23] Smith CV, Phelan JP, Paul RH, et al. Fetal acoustic stimulation testing. II. A randomized clinical comparison with the nonstress test. Am J Obstet Gynecol 1986;155(1):131-4.

[24] Damania K. Biophysical methods of assessing fetal well-being. Chapter 31. In: Krishna U, Tank DK. eds. Pregnancy at risk - current concept. $4^{\text {th }}$ edn. New Delhi: Jaypee Bros 2001:172-6.

[25] Williams K, Farguharson D, Bebbingtomm, et al. A randomized controlled clinical trial comparing NST versus Doppler velocimetry as a screening test in high risk population. Am J Obstet Gynecol 2000;182:109.

[26] Manning FA, Platt LD, Sipos L. Antepartum fetal evaluation: development of fetal biophysical profile. Am J Obstet Gynecol 1980;136(6):787-95.

[27] Magann EF, Chauhan SP, Kinsella MJ, et al. Antenatal testing among 1001 patients at high risk: the role of ultrasonographic estimate of amniotic fluid volume. Am J Obstet Gynecol 1999;180(6 Pt 1):1330-6.

[28] Boran C, Morgan MA, Garite TJ. The impact of amniotic fluid volume assessed intrapartum on perinatal outcome. Am J Obstet Gynecol 1995;173(1):167-74.

[29] Banks EH, Miller DA. Perinatal risks associated with borderline amniotic fluid index. Am J Obstet Gynecol 1999;180(6 Pt 1):1461-3.

[30] Jeng CJ, Lee JF, Wang KG, et al. Decreased amniotic fluid index in term pregnancy. Clinical significance. J Reprod Med 1992;37(9):789-92. 